\title{
Analysis of Policy Evaluation and Model of ASN Management Improvement in terms of Planning, Recruitment, and Competency Development Aspects
}

\author{
Robby Kurniawan ${ }^{1}$, Aries Djaenuri ${ }^{2}$, Hadi Prabowo ${ }^{3}$, Sampara Lukman ${ }^{4}$ \\ 1,2,3,4 Institut Pemerintahan Dalam Negeri (IPDN), Indonesia \\ Email: robby.biroren@gmail.com
}

\begin{abstract}
This study aims to analyze the evaluation of ASN management policies at the Ministry of Transportation and the provincial government of DKI Jakarta and the appropriate model for improving ASN management in planning, recruitment, and potential development. The approach used in this study is to use action research-based Soft Systems Methodology (SSM) as a research method with systems thinking approach. This research method's selection was carried out considering that ASN management is a Human Activity System with various problems involving many agencies. There are multiple laws and regulations used. The results showed that the evaluation analysis from the planning aspect showed that the policies, their formulation, and their dissemination had been carried out well; The recruitment aspect indicates that there is still something that needs to be addressed, especially in the recruitment of CPNS, PPPK, and open selection of positions; Aspects of competency development receive greater attention, especially in terms of improving performance, cost efficiency and achieving organizational goals. This study also develops concepts to improve ASN management in the form of a framework that includes: foundational theories, foundational theory \& empirical facts as fundamental to formulate research interest, and research contributions.
\end{abstract}

Keywords: State Civil Apparatus (ASN), Management, Planning, Recruitment, Competence.

\section{A. INTRODUCTION}

As one of the leading skilled resources, humans are needed in various fields because it is a global demand that cannot be postponed and negotiated. In an organization, Human Resources need to be managed and utilized productively (Fathoni, 2019; Thoha, 2003). The management and utilization of Human Resources are aimed at achieving organizational goals and the development of the individual concerned in the scope of work. Human existence is the main asset (wealth) that plays a vital role in achieving organizational goals; human resources dramatically determine the level of effectiveness and efficiency of the organization in realizing its goals (Morley et al., 2006; Sonnenberg et al., 2011).

Human resource development is a process of improving humans' quality or ability to achieve national development goals and has an essential role in achieving success (Yuniarsih \& Suwatno, 2008). The critical role of human resources is as necessary capital to carry out management by increasing efficiency, quality, and service distribution. Educational efficiency is obtained through the professionalism of Human Resources in managing existing resources and all interests. Therefore, 
existing resources must be used optimally to increase management efficiency (Becker \& Gerhart, 2006; Arrowsmith \& Parker, 2013).

The implementation of public services in Indonesia still has various problems that need to be resolved. However, there has been a significant increase in their execution, but it is still lagging behind other countries in Asia when referring to various global indicators. One of the things that can raise public services in Indonesia is the management aspect of the state civil apparatus (ASN). For example, one of the references, according to Friedman (2007), explains that human resource management is considered a management field capable of bringing strategic contributions to organizations. Human resource management is closely related to human resource assets' use to achieve organizational goals and organizational continuity and success (Becker et al., 2001; Stavrou \& Brewster, 2005; Baron \& Armstrong, 2007). Organizations will benefit from adopting 'best practices' to manage human resources (Becker et al., 2001). To maximize human resources' utility, it is often necessary for an organization to take advantage of the 'best practices' of human resource management (Bushardt et al., 2011).

Concerning human resource management or ASN, if the context is a public sector organization, Indonesia still has quite a lot of homework to do. The thing that is often highlighted is the low quality of ASN. According to some experts, this is due to recruitment, appointment in positions, and promotions that have not been based on objective considerations (Hasibuan, 2005). Besides, the rampant practice of spoil systems in ASN management, where positions are given to officials related to the ruling party (Blunt et al., 2012). This practice has been around for a long time but has grown since the implementation of direct elections in the regions. The increase in spoil system practice is one of the drivers of high levels of corruption among politicians and civil servants (Indonesia, 2017).

ASN management is seen as an interconnected system starting from planning, recruitment, competency development, performance appraisal, promotion, rotation, and career, to retirement (Oktarina \& Mustam, 2018). However, in its implementation, several problems occur concerning the ASN's management that affects Indonesia's performance of public services. In responding to the critical role of human resources, the government has made efforts to reform the bureaucracy, targeting changes in the HR area. The various problems that have been described above in ASN and the challenges that must be faced in the global context have led the government to reform the personnel system with the enactment of Law No. 5 of 2014 concerning the State Civil Apparatus. The hope is that there will be a change in the Indonesian staffing system from prioritizing rules (rule-based) to a performancebased bureaucracy, then achieving dynamic governance in 2025 (KemenPANRB, 2013).

Law No. 5 of 2014 concerning ASN seems to want to give new hope so that ASN's management can be carried out following the merit system. The various notes above seem to be answered by the existence of Law no. 5 of 2014 concerning the ASN. ASN management, which must be based on a merit system, is mandated in 14 
(fourteen) aspects, namely (1) preparation and determination of needs, (2) procurement, (3) ranks and positions, (4) career development, (5) career patterns, (6) promotions, (7) transfers, (8) performance appraisals, (9) payroll and allowances, (10), awards, (11) discipline, (12) dismissal, (13) pension and old-age benefits, and ( 14) protection. As mandated by Law no. 5 of 2014, changes in ASN management should be able to contribute to the achievement of prioritized national development targets.

Therefore, it is interesting to study the analysis of the state civil servants' management policy evaluation to be carried out by taking the object of research. Furthermore, the management aspects of ASN that need to be studied become the next issue. Of the 6 (six) aspects of ASN management that need to be carried out by the government, this research will only focus on 3 (three) aspects which, according to researchers, are very important related to improving the quality of ASN in the bureaucracy, namely parts of planning, recruitment, and developing ASN competence.

\section{B. METHOD}

The approach used in this research is to use the Soft Systems Methodology (SSM) based on action research (Uchiyama, 2009) as a research method with systems thinking approach (Checkland, 1981). SSM is based on the idea that human and organizational factors cannot be separated from problem-solving. This research method's selection was carried out considering that ASN management is a Human Activity System with various problems involving many agencies. There are multiple laws and regulations used.

Soft Systems Methodology (SSM), which is included in action research, can be used for research interest, problem-solving interest, or it could be both (dual imperative) (Hardjosoekarto, 2012; McKay and Marshall, 2001). Research Interest departs from factual issues in a particular theory (theoretical point), while problemsolving interests depart from factual issues that occur in the real world (Hardjosoekarto, 2012). Currently, SSM research has developed between the poles of Research Interest and problem-solving interest. This study takes the two bars because this study departs from factual issues that occur in the real world.

\section{RESULT AND DISCUSSION}

\section{Analysis of Management Policy Evaluation (Problem Solving Interest)}

Making ASN ideal and competitive in globalization is a public demand and a target that must be achieved. To compete with other countries in the era of industrial revolution 4.0, the government has designed a road map for the SMART ASN program, which is targeted to be realized in 2024. Three main targets for discovering SMART ASN in 2019, namely: First, ASN planning, by opening up ASN formation/qualification following national development and regional potential. Second, ASN's procurement is transparent, objective, and fair to restore public trust and capture the nation's best sons and daughters. Third, increasing professionalism, 
namely improving competence, qualifications, and performance as mandated by the ASN Law. The three aspects covered in the SMART ASN are relevant to the things evaluated by this study.

From the evaluation of ASN management policies in terms of planning, recruitment, and competency development aspects, several notes need to be considered to realize the ASN SMART program. Some of these notes are as follows.

a. Planning Aspects That Need To Be Improved

These employee planning activities can also be applied as a consideration in planning ASN's needs within government organizations. This can be seen from the definition or definition of ASN planning, which is the activity of predicting the desired future conditions, which include the number, type of expertise, level of competence to ensure the availability of human resources following the needs of the organization to match the fields of position with the available knowledge or skills so that organizational goals can be achieved effectively and efficiently. The objectives of employee planning are generally categorized into three stages: short, medium, and long term employee planning. Short-term employee planning (annual perspective) aims to determine the prediction of vacant positions/positions in the next year that must be filled, both in number and qualifications within an organization. The objective of medium / long term employee planning (maximum of the next 5 years) is to determine employee demand predictions to maintain and develop its competitive existence. The purpose of long-term employee planning is to obtain civil servant figures who are competent in carrying out tasks professionally and are responsible for carrying out government and development tasks, and are free from corruption, collusion, and nepotism (KKN).

Good employee planning will improve employee utilization, adjust employee activities and future needs efficiently, increase efficiency in recruiting new employees, and complete staffing information to help staffing activities and other organizational units. Through planning, it is possible to know the weaknesses or the advantages of the needs so that new employee recruitments, promotions, or transfers can be carried out proactively not to disrupt organizational activities.

The formulation of ASN needs is an analysis of the number, type, and status of ASNs needed to effectively and efficiently carry out the main tasks to support the workload of Government Agencies. Thus, each government agency must submit suggestions for employee formation every year, consisting of the number and positions required, and make projections of needs for 5 (five) years.

There are several problems related to this aspect of ASN planning. First, there are many overlapping regulations in PNS planning. Second, specifically for regions, there are differences in planning formats (Anjab and $A B K$ ) between those determined by the Menpan and those determined by BKN and the Ministry of Home Affairs. Third, the determination of the number of appointed CPNS formations is not following the results of PNS planning in each government agency. Fourth, the lack of quality of employees and communication between employees who are given responsibility and authorized work units related to personnel in carrying out ASN 
planning, especially the education and competence of these employees, so that the preparation of Anjab and ABK cannot be adequately implemented. Fifth, the lack of attention from the leadership of the work unit and the PPK, so that employees' interest to become JFT is very minimal. Sixth, there are limitations in the budget because each agency's personnel expenditure varies in terms of carrying out employee development, especially JFT and paying job allowances.

b. Improvement in CPNS Recruitment

The recruitment of CPNS is essential in fulfilling employees' best cadres for the government bureaucracy to improve performance. It is undeniable that civil servants share the job market that is widely targeted by the community as a productive workforce for fresh graduate university graduates. CPNS recruitment is carried out to meet ideal employee needs; therefore, every government agency needs to rationally compile civil servants' needs based on a job analysis and workload analysis. In terms of accepting CPNS, the government determines the formations intended for central government agencies and regional government agencies.

Many CPNS selection participants show that working in the government sector is a favorite profession for people in Indonesia in general. The purpose of holding the CPNS selection is to produce competent, dignified, professional, and integrity resources for civil servants of the state apparatus. As stated by Nitisemito (1996), this is that the objective of the selection process is to get the right employees, the right man in the right place. According to him, in the selection process, he must get the right workforce in the correct position. This opinion inspires that in the government sector, the procurement and recruitment of CPNS need to be carried out strictly, selectively, and transparently so that anyone who follows and has the opportunity to become CPNS is very wide open.

By paying attention to the CPNS selection process's implementation, several obstacles need to be criticized as an improvement in the CPNS selection in the following years. Some of these obstacles, such as; committee, planning, server, score scores, determination of passing grades and rankings, cooperation between agencies, etc. All this needs correction to provide adequate public services in terms of CPNS selection according to available service standards. Besides, inadequate physical infrastructure, such as computer and network devices with minimal technological reach, and online registration, are often subject to maintenance. Then there was an inconsistency in the system or provisions and qualifications that were informed at the CPNS recruitment opening. The implementation of CPNS selection also needs to pay attention to the provisions of existing laws and regulations and various government policies that have been established.

Technical problems in implementing CPNS selection related to planning, preparation, time, coordination, and the selection committee. This has resulted in a less positive perception that occurs in the community regarding the image of public services (CPNS selection), which seems to be not optimal, where some agencies are still constrained by the infrastructure and facility components of the Computer Assisted Test (CAT) selection. Other infrastructure problems originate from the 
server; this can be seen from the registrant's post on the official BKN Twitter account. Some registrants have difficulty accessing the website, which has been down several times, so that the account registration process requires an additional registration period. Another problem is the mismatch of the CPNS selection process during the administrative selection stage, the unclear determination of the terms of the scientific family so that participants who should meet the requirements according to the required forms are not passed.

c. Straightening PPPK Policy Direction

PPPK needs to be understood differently from contract employees, nonpermanent employees, honorary staff, etc. which have never been adequately managed. Contract Employee Management is only handled by the smallest units of government agencies, which are not standardized. Contract Employee Management is also not operated following fundamental principles in modern management principles that prioritize increased professionalism. Contract employees' existence is not regulated thoroughly by applying standard norms, standards, and procedures, resulting in unclear roles and functions. The procurement of contract employees has more political nuances, is only used as a political vehicle, and the recruitment is full of KKN elements. With a procurement system that is not professional and full of interests, contract employees' quality and competence are in doubt.

The definition of a Contractor or Honorary Person is someone who is appointed by a Civil Service Officer (PPK) or another official in the government to carry out specific tasks in government agencies or whose income is borne by the APBN and APBD (PP 48/2005 Article 1). Hiring an Honorary Staff is carried out through administrative selection, discipline, integrity, health, and competence. Meanwhile, PPPK is an Indonesian citizen who meets specific requirements appointed based on a work agreement for a certain period in carrying out government duties (Law Number 5 of 2014 Article 1). PPPK acceptance is carried out through objective selection based on competence, qualifications, needs, and other requirements required in the position.

Considering the requirements for the appointment of Honorary Staff and PPPK, it is clear that the selection procedure is a competency test. The competency test is basically to match the qualifications of the position needed and the qualifications of the prospective employees who will occupy the position. This means that the procedure for recruiting Honorary Staff and PPPK must go through a selection and competency test, unlike what has happened so far where all agency units appoint Honorary Staff without going through a piece. Likewise, if the Honorary Staff or PPPK, if they want to occupy the position of CPNS, must apply and follow the procedures as required, not be appointed automatically.

The birth of the ASN Law is new hope for starting PPPK management professionally. As mandated by the ASN Law that PPPK management is based on a merit system that emphasizes an objective comparison between the qualifications, competencies, and performance required by a position with the capabilities, competencies, and implementation of the candidate with recruitment, appointment, 
and placement in line with governance well. PPPK management policy directs that every government agency is required to compile the number and type of PPPK positions required based on a job analysis and workload analysis.

PPPK procurement is carried out through planning, determining needs and formations, announcing vacancies, application, selection, and appointment. A performance appraisal is carried out based on a work agreement at the individual, unit, and agency-level by taking into account targets, goals, results, benefits achieved, and employee behavior. PPPK performance appraisal is carried out in an objective, measurable, accountable, participatory, and transparent manner. Besides, PPPKs are given fair and decent salaries and benefits according to workload, competency development, and rewards and protection.

d. The dichotomy of the Merit System and the Politicization of the Bureaucracy in Appointing ASN Positions

The birth of Law Number 5 of 2014 concerning State Civil Servants is a new hope for the implementation of ASN management to produce competent, reliable, and competitive ASNs through a merit-based management system. The ASN management system merit is an approach that emphasizes ASN's power by basing the suitability of employee expertise with the qualifications of the position. The mismatch between employee competence and job qualifications is a significant problem for ASN's existence, which is in the public spotlight. One of the causes is the lack of professional implementation of ASN management, which impacts the lack of ASN competence. As stated by Ashari (2010), there is a need for empowerment to unravel the everyday problems of government employees, such as (1) the practice of spoil system and incompetence in the recruitment and selection system for employees; (2) Staffing structure, especially concerning quality and quantity as well as a distribution which is not ideal; (3) The level of efficiency and effectiveness as well as employee performance is not optimal; (4) Unclear, transparent and competitive employee career systems and patterns; (5) The level of discipline, work ethic and work culture of employees is still low.

The poor management of ASN has been exacerbated by the politicization of the bureaucracy in the administrative sphere, namely the intervention of political officials in the appointment of ASN career positions. As stated by Daniarsyah (2017), that in the history of the administration of Indonesia, it is full of bureaucratic politicization, where the position of the bureaucracy cannot be neutral towards the political forces that play in government. ASN appointments are chosen and promoted not based on a merit system. Still, more due to the bureaucracy's politicization, even dismissal or demotion cannot be separated from the nuances of bureaucratic politicization.

To ensure a clean government bureaucracy, free of corruption, collusion, and nepotism $(\mathrm{KKN})$, and apart from political intervention, it is necessary to implement a merit-based ASN management system. In the explanation of the ASN Law, it is stated that the government is expected to be able to create professional, competent, and competitive apparatus through the implementation of ASN management based 
on a merit system, or a system of recruitment, appointment, placement, and promotion of employees based on qualifications, competencies, and performance. The management of ASN is ideally implemented openly and competitively, in line with good governance. Therefore, the implementation of ASN management based on the merit system is a top priority, and the politicization of the bureaucracy must be eliminated. The dichotomy of the merit and politicization system was immediately resolved with a commitment to bureaucratic reform.

Merit is the central pillar for the implementation of management or good governance in all aspects, including the appointment of positions in government employees' direction. This is, as stated by Woodard et al. (2000), that in public management, merit acts as a value or principle which connotes fairness, equity, and reward in public office (public employment) based on achievement, not based on political principles or discrimination or other favoritism. As a fundamental principle, the merit system must be carried out in the practice of implementing ASN management.

The merit system is a policy and management of ASN which is based on qualifications, competence, and performance fairly and reasonably without distinction of political background, race, color, religion, origin, gender, marital status, age, or condition of disability. . This is as stated in Article 51 of the ASN Law that ASN management is carried out based on a merit system. The principle of the merit system aligns the aspects of competence (competence), qualifications (quality), work performance (performance), fairness (fairness), and open (open). In the appointment of a position, merit should be a value that is upheld to get ASN professionalism.

The dilemma of the system of merit and politicization is felt in every ASN appointment. Fulfillment of various demands from the appointment of positions is still largely made for political purposes, many of which are carried out with KKN practices' intrigue. The commitment and integrity of the Civil Service Officer (PPK) is the key to the successful application of the principle of merit in ASN appointments. The purpose of implementing the merit system is to find competent ASN officials who can be relied on to provide public services (public service) professionally.

The political dichotomy in state administration must be avoided for the administration of government. In government, a distinction must be made between officials who carry out state administration's political functions and functions. The political process in the making of policies (policies) or the expression of the state's will, while state administration is the implementation of policies. The politicization of the bureaucracy, in essence, the government is on 2 (two) sides; (1) comes from the side of the political party which intervenes in the bureaucracy; (2) comes from the executive itself who politicizes the bureaucracy for its interests (power), but both have the same interests, namely to perpetuate or maintain control (Martini, 20014).

According to Harold Crouch, bureaucratic-polity in Indonesia contains 3 main characteristics, namely; first, the dominant political institution is the 
bureaucracy; second, other political institutions such as parliaments, political parties, and interest groups are in a weak condition, so that they are unable to balance or control the power of the bureaucracy; third, the masses outside the bureaucracy are politically and economically passive, part of which is a weakness of political parties and mutually strengthens the bureaucracy (Martini, 20014).

e. ASN Competency Development Must Be Related to ASN Career Patterns

The role of every ASN as a Human Resource in government organizations is vital. ASN is the main driving factor in running government organizations. Therefore, for government organizations to run well, ASN is needed that is reliable and has the capabilities that the organization needs. This is in line with Law Number 5 of 2014 concerning State Civil Servants as stated in its explanation that to carry out public service duties, government tasks, and specific development tasks, ASN employees must have ASN professions and management based on a merit system or objective comparisons between qualifications, competencies, and performance required by positions with the capabilities, competencies, and implementation of candidates in recruitment, appointment, placement and promotion in places that are carried out openly and competitively, in line with good governance. This is also in line with Government Regulation No.11 of 2017 concerning Civil Servant Management Article 162 that career development, competency development, career patterns, transfers, and promotions are civil servant career management, which must be carried out by applying the principle of a merit system.

However, the reality that is often found in the opposite; there is a gap between the competence and actual capabilities of ASN and the ideal competencies and abilities that the organization needs. This will undoubtedly have an impact on organizational performance and career development for ASN. ASN career development is carried out based on qualifications, competencies, and work performance. According to Article 69 of the ASN Law, ASN career development is carried out based on qualifications, competencies, performance appraisals, and government agencies' needs. The competencies in question are technical competences, managerial competences, and socio-cultural competencies. For the competence of employees to meet the desired standards, competency development is required.

Meanwhile, Article 70 states that every ASN employee has the right and opportunity to develop competencies. Competency development, among others, through education and training, seminars, courses, and upgrades. Competency development is evaluated by Competent Officers and used as one of the bases for appointment and career development.

Government Regulation Number 11 of 2017 in Article 203 states that competency development is an effort to meet ASN's competency needs with competency standards for Position and career development plans. Each civil servant's competency development is carried out for at least 20 (twenty) lesson hours in 1 (one) year. Whereas for Government Employees with a Work Agreement (PPPK), the implementation of competency development as referred to in Article 39 
paragraph (1) shall be carried out for a maximum of 24 (twenty-four) learning hours in 1 (one) year work agreement period (PP Number 49 of 2018 concerning Government Employees With Work Agreement). Based on this, one of the methods to develop ASN competencies is to use the Individual Development Plan (IDP). The IDP method will make it easier for ASNs to identify the tasks that must be done for competency development and achieve the desired goals.

Then, there is career development, an opportunity given by government institutions to ASN employees to increase their strategic positions through a career path. The problem in government agencies is that so far, there has been no clear plan for ASN career development. The lack of clarity about the ASN career pattern in government agencies shows one proof that the ASN development plan has not been designed optimally. Career patterns are a reference for career development because a career path can direct his career direction. It is very naïve to plan or manage a career without a career pattern. In addition to being a career pathway pattern, career patterns also motivate employees to carry out their roles, main tasks, and functions. The existence of a clear career pattern will assure ASN employees in determining their future careers.

Another problem in ASN career development is that every time there is an ASN position vacant or left behind, there is no direct / can replace it. This shows the absence of ASN career development planning, especially in leadership succession. The ASN leadership succession only occurs shortly or after the position is vacant; sometimes, the process does not go through a recruitment and selection process. Position selection has not been fully transparent and objective based on the principle of merit. Besides, the transfer and promotion of ASN positions, in managerial/structural and functional/technical terms, do not yet refer to the ASN's performance. Even the available selection of ASN positions that has been carried out is seen as still not producing competent officials as expected. This shows that ASN's career development is not optimal. The low commitment of stakeholders in implementing merit-based ASN management policies is a separate problem that must be resolved.

\section{Model of ASN Management Improvement (Research Interest)}

Besides being oriented to problem-solving interest, this research is also introduced to research interest. To answer the research interest orientation, this research resulted in developing concepts to improve ASN management. The effect of this concept is achieved in parallel with the problem-solving interest process. In other words, this research carries out a dual cycle process; that is, in addition to producing problem-solving suggestions, it also generates new knowledge of related concepts. To develop research interest, the framework used is divided into three essential parts, namely (1) foundational theories, (2) foundational theory \& empirical facts as necessary to formulate research interest, and (3) research contributions.

First, related to foundational theories. This research examines and explains the fundamental theories used. This study has reviewed the evaluation of ASN 
management policies through 7 (seven dimensions). Besides, in his explanation, there is a relationship between institutions studied through a new institutional framework known as the New Institutional Economics and Sociology (NIES). NIES is an interdisciplinary science that combines various disciplines such as economics, law, organizational theory, political science, sociology, and anthropology, intending to understand social, political, and commercial institutions.

One of the opinions developed in this study is the opinion of Victor Nee in 2003. According to him, the institutional framework consists of 3 (three) levels: the macro, meso, and micro levels. At the macro level, there is an institutional environment that has a role in terms of regulation. This role is the government's authority in the life of the nation and state. However, in carrying out its function, there is an influence from the environment, as explained by Winarno (2005), related to public policy. According to him, public policy is a policy developed by government agencies and government officials influenced by non-government actors and factors. Winarno's explanation is in line with Eyeston's (1971), who explains that public policy can be defined as the relationship between government and its environment.

Even though there is an influence from the environment, when something has been determined to become a government policy, the parties who are the object of the policy must obey the rules in the policy. Dye (1975) explained that public policy is whatever the government chooses to do and not do. Concerning the NIES theory, this government policy applies to parties at the meso and micro levels.

At the meso level, there is a role played by the parties at that level. In the context of NIES, this role is collective action and monitoring \& enforcement. Regarding collective action, Olson (1971) explains that this role is related to interest groups. Referring to Olson (1971), the essential factors that determine collective action's success are the size, homogeneity, and objectives of the related groups. Regardless of the interests of interest groups, referring to Ostrom in Nabli and Nugent (1989), this collective action is designed to produce cooperative solutions to solve difficult problems and achieve efficiency in using resources. Regarding monitoring \& enforcement, Ménard and Shirley (2008), referring to Gary Miller's opinion, explained that this is related to the principal-agent theory. Concerning the principal-agent idea with NIES, the parties at the meso level are the principal, while the micro-level parties are the agents.

At the micro-level, according to the NIES theory, there is decoupling and compliance. Nee (2005) defines decoupling as a mismatch between formal policy practices in the field. As for compliance, it relates to efforts made to implement proper legal arrangements as expected. Submission will occur if the actors who become policymakers always take the real conditions that occur in the field to carry out formal policies.

The micro-level is related to the organization of the market (market). There is no authority relationship between the two parties in a pure market transaction, and there is no central structure; the pricing system provides "high powered" incentives 
for both parties that adapt to changing market conditions. In a market with many transactors, partner identity is irrelevant, and partner selection is not required. There is no interdependence between partners in an "unclear" market, so transaction costs are negligible.

Due to market failures and transaction costs, the hierarchy will replace the market. Interdependence makes partner identities important, creating the need for partner selection mechanisms. As a company that grows in scale and scope, it requires general staff and administrative controls to coordinate the company's activities. Administrative control mechanisms include systems planning, information sharing, integration, monitoring, and performance evaluation. In the perspective of transaction costs, markets and hierarchies are polar models of government in a unidimensional unit, whereas "the hybrid model (hybrid) displays intermediate values." In particular, this hybrid form is characterized by semi-strong incentives, mid-level administrative apparatus displaying semi-strong adaptations of both types, and developing semi-legalistic contract law regimes (Williamson, 1991).

Then, the research found empirical facts that can enrich ASN management. Therefore, the second part of the research interest framework is to combine the results of the analysis of foundational theories with field findings (empirical facts). Field findings (empirical facts) constitute valuable intellectual property because the concept development carried out is following the prevailing conditions.

Furthermore, the analysis of foundational theories and empirical facts has resulted in research contributions. These results are the third part of the framework of research interest. This research contribution is the result of developing concepts that become research interests oriented towards research interest. It is hoped that developing this theory can become new knowledge so that it can be adopted both theoretically and practically.

By adopting the NIES theory, three levels of ASN management policy were formulated. The three levels are the macro, meso, and micro levels. Each level has its characteristics, but that does not mean that it is separate from one another.

The macro-level is a regulatory aspect that focuses on policy formulation and direction. Policy formulation is a process carried out by actors at the macro level. With the policy formulation, the legal umbrella regarding ASN management becomes evident. Then, another thing that becomes the focus of the macro level's regulatory aspect is policy direction. The role of actors at the macro level is in formulating policies and directing policies clearly to the targeted agencies.

The meso level is controlling governance. At this level, parties at the controlling governance level adhere to two roles: collective action and monitoring \& enforcement. The collective action aspect that occurs at the meso level focuses on communication and coordination activities. With effective communication and coordination, the division and implementation of tasks will become more apparent. The second role is monitoring and enforcement, showing that the parties at the level of controlling governance are carrying out supervisory activities. In this role, 
supervision is carried out in an orientation toward achieving results and facilitating coordination.

As for the micro-level, there are implementers. At this level, the parties carry out interactions and transactions to fulfill two aspects, namely avoiding decoupling and creating compliance. As for the micro-level, there are implementers. At this level, the parties carry out interactions and transactions to fulfill two aspects, namely avoiding decoupling and creating compliance.

Policy implementation at the micro-level must be evaluated from 7 (seven) dimensions, namely (1) policy, its formulation, and dissemination, (2) social, political and economic context, (3) leadership for policy implementation, (4) stakeholder involvement in policy implementation, (5) planning implementation and resource mobilization, (6) operations and services, and (7) feedback on progress and results.

The explanation above is the result of research that contributes to the research interest. This contribution can provide new knowledge to improve ASN management in particular or employees in general.

\section{CONCLUSION}

From the ASN Management Policy evaluation analysis, a review of the planning aspect shows that the policies, their formulation, and their dissemination have been carried out well. Social, political, and economic contexts influence ASN planning. The recruitment aspect shows that there is still something that needs to be addressed, especially in recruiting CPNS, PPPK, and open selection for High Leadership Positions. The competency development aspect shows the priority areas and gets more attention than the planning and recruitment aspects. The challenge of improving organizational performance, the efficient use of personnel expenditure budgets, and various national policy directions have caused this aspect of competency development to receive more attention. Although it is still necessary to measure whether it can improve organizational performance, increase budget efficiency, and achieve the national development direction in terms of results.

As a form of research interest, this research develops concepts to improve ASN management from the research process carried out. The framework undertaken is in the way of compiling (1) foundational theories, (2) foundational theory \& empirical facts as essential to formulate research interest, and (3) research contributions. To improve ASN management, stakeholders need to analyze macro, meso, and micro levels before evaluating them. The macro-level is a regulatory aspect that focuses on policy formulation and direction. The meso level controls governance, which is attached to two roles, namely collective action and monitoring \& enforcement. As for the micro-level, some implementers must fulfill two aspects, namely avoiding decoupling and realizing compliance. Policy implementation at the micro-level must be evaluated from 7 (seven) dimensions, namely: policy, its formulation, and dissemination, social, political and economic context, leadership for policy implementation, stakeholder involvement in policy implementation, planning 
implementation and resource mobilization, operations and services, and feedback on progress and results.

\section{REFERENCES}

1. Arrowsmith, J., \& Parker, J. (2013). The Meaning of 'Employee Engagement' for the Values and Roles of The HRM function. The International Journal of Human Resource Management, 24(14), 2692-2712.

2. Baron, A., \& Armstrong, M. (2007). Human Capital Management: Achieving Added Value through People. Kogan Page Publishers.

3. Becker, B. E., Huselid, M. A., Huselid, M. A., \& Ulrich, D. (2001). The HR Scorecard: Linking People, Strategy, and Performance. Harvard Business Press.

4. Becker, B., \& Gerhart, B. (1996). The Impact of Human Resource Management on Organizational Performance: Progress and Prospects. Academy of Management Journal, 39(4), 779-801.

5. Blunt, P., Turner, M., \& Lindroth, H. (2012). Patronage's Progress in PostSoeharto, Indonesia. Public Administration and Development, 32(1), 64-81.

6. Bushardt, S. C., Glascoff, D. W., \& Doty, D. H. (2011). Organizational Culture, Formal Reward Structure, and Effective Strategy Implementation: A Conceptual Model. Journal of Organizational Culture, Communication, and Conflict, 15(2), 57-71.

7. Checkland, P., \& Holwell, S. (1998). Action Research: Its Nature and Validity. Systemic Practice and Action Research, 11(1), 9-21.

8. Daniarsyah, D. (2017). Penerapan Sistem Merit dalam Rekrutmen Terbuka Promosi Jabatan Pimpinan Tinggi ASN (Suatu Pemikiran Kritis Analisis). Civil Service Journal, 11(2 November).

9. Dye, T. R., \& Dye, T. R. (1992). Understanding Public Policy. Englewood Cliffs, NJ: Prentice-Hall.

10. Eyestone, R. (1971). The Threads of Public Policy: A Study in Policy Leadership. Ardent Media.

11. Fathoni, A. (2019). Organisasi dan Manajemen Sumber Daya Manusia. Jakarta: Rineka Cipta.

12. Friedman, B. A. (2007). Globalization Implications For Human Resource Management Roles. Employee Responsibilities and Rights Journal, 19(3), 157-171.

13. Hardjosoekarto, S. (2012). Soft Systems Methodology: (Metode Serba Sistem Lunak). Jakarta: UI Press.

14. Hasibuan, M. S. (2005). Manajemen Sumber Daya Manusia. Jakarta: Bumi Aksara.

15. Hendry, C., Woodward, S., Bradley, P., \& Perkins, S. (2000). Performance and Rewards: Cleaning Out the Stables. Human Resource Management Journal, 10(3), 46-62.

16. Indonesia, L. A. N. R. (2017). Manajemen ASN: Modul Pelatihan Dasar Calon PNS. Jakarta: Lembaga Administrasi Negara.

17. Komisi Aparatur Sipil Negara. (2018). Penilaian Penerapan Sistem Merit dalam Manajemen ASN di Instansi Pemerintah Tahun 2018. Jakarta: KASN. 
18. McKay, J., \& Marshall, P. (2001). The Dual Imperatives of Action Research. Information Technology \& People.

19. Morley, M., Valverde, M., Ryan, G., \& Soler, C. (2006). Distributing HRM Responsibilities: A Classification of Organizations. Personnel Review.

20. Nabli, M. K., \& Nugent, J. B. (1989). Collective Action, Institutions, and Development. In Contributions to Economic Analysis (Vol. 183, pp. 80-137). Elsevier.

21. Nee, V. (2005). The New Institutionalism in Economics and Sociology. The Handbook of Economic Sociology, 2, 49-74.

22. Nitisemito, A. S. (1996). Manajemen Personalia. Jakarta: Ghalia Indonesia.

23. Oktarina, A., \& Mustam, M. (2018). Manajemen Sumber Daya Aparatur Sipil Negara (ASN) dalam Rangka Reformasi Birokrasi di Badan Kepegawaian Pendidikan dan Pelatihan Daerah (BKPPD) Kota Pekalongan. Journal of Public Policy and Management Review, 7(2), 40-54.

24. Olson, M. (1971). The Logic of Collective Action: Public Goods and the Theory of Groups, Second Printing with a New Preface and Appendix (Vol. 124). Harvard University Press.

25. Sonnenberg, M., Koene, B., \& Paauwe, J. (2011). Balancing HRM: The Psychological Contract of Employees. Personnel Review.

26. Stavrou, E. T., \& Brewster, C. (2005). The Configurational Approach to Linking Strategic Human Resource Management Bundles with Business Performance: Myth or Reality?. Management Revue, 186-201.

27. Thoha, M. (2003). Perilaku Organisasi Konsep Dasar dan Aplikasinya. Jakarta: Grafindo Persada.

28. Uchiyama, K. (2009). Preliminary discussion of Validity and Legitimacy of SSMbased AR. Action Research for Improvement in Schools, Communities, and Organizational Spaces what is to be Done? 67.

29. Williamson, O. E. (1991). Economic Institutions: Spontaneous and Intentional Governance. Journal of Law, Economics, E Organization, 7, 159-187.

30. Winarno, B. (2005). Implementasi Kebijakan Publik Teori dan Proses. Jakarta: Buku Kita.

31. Woodard, C. A. (2005). Merit by Any Other Name-Refraining the Civil Service First Principle. Public Administration Review, 65(1), 109-116.

32. Yuniarsih, \& Suwatno. (2008). Manajemen Sumber Daya Manusia. Bandung: Alfabeta. 